\title{
集合住宅ファサードの幾何学的形態の変化と景観の印象評価の構造分析 CHANGES IN GEOMETRICAL FORM OF APARTMENT BUILDING FAÇADE : CONJOINT ANALYSIS OF IMPRESSION AND EVALUATION OF STREETSCAPE
}

\author{
佐伯 洋*, 岸本達也** \\ Yoh SAEKI and Tatsuya KISHIMOTO
}

\begin{abstract}
In streetscape, shapes of buildings are important to decide impressions of streets. We often align wall lines and height of buildings to give a sense of unity. At the streetscape overly unified, however, we feel to be monotone and lacking lively, so it's important to understand the relation between shapes of buildings and impressions of streetscapes.

We reproduce various shapes of façades using CG technology. Through the experiment and analysis of it, we reveal the relation between the structure of evaluation and characteristics of desirable shapes of façade. We also reproduce various impression facades and simulate the evaluation of landscape.
\end{abstract}

Keywords:Shape of building, Set Back, Streetscape, Rations of impression, Preference 建物形態, 景観, 印象評価, SD 法, コンジョイント分析

\section{1. 研究背景および目的}

街路景観において、建物の形態はその街路の印象を決定する重要 な要素の一つである。特に沿道型の街路では、魅力的な街路を形成 する一つの方法として、壁面線や高さなどを揃えて統一感を与えて いる事例が多く見られる。しかし、過度に統一された景観は、単調 で活気や賑わいに欠ける印象を与えてしまう場合もある。そのため、 魅力的な景観を形成するうえで、建物形態と街路景観の印象との関 係をより詳しく把握することは重要であるといえる。本研究では、 集合住宅によって沿道景観を構成する建物ファサードの望ましい形 態的特徴について CG を用いた形態シミュレーションと被験者実験 によって明らかにする。

建物の形態と景観の印象について扱った既往の論文としては、篠 原、屋代らの研究がある ${ }^{1)}$ 。篠原らはCGにより再現した街路におけ る沿道建物の高さ、間口幅、およびセットバック量を操作し、それ と囲まれ感、圧迫感および統合感との回帰式を求めている。その結 果、「囲まれ感」「圧迫感」は街路総幅員と沿道建物高さ平均との比 で規定されること、「統合感」は沿道建物高さの変異係数により規定 されることが明らかとなった。また、「全体の良否」は沿道建物の「統 合感」が適度な乱れのときに最も高くなるが、「圧迫感」や「閉鎖感」 が強まってくると悪く評価されることも明らかとなった。

奥、紙野、船橋らは、3 次元ステレオグラムを用いて建物高さと
壁面線が連続している街路を再現し、その中の 1 建物の形態変化(高 さ、間口幅、壁面線位置) が都市景観の連続性評価に及ぼす影響に ついて明らかにしている ${ }^{2)}$ 。その結果、「連続性」には高さと壁面線 位置が影響していることが明らかとなった。

鄭、奥、船越らは幹線街路景観を対象に、沿道建物の高さとセッ トバックの変化を 3 次元立体視の $\mathrm{CG}$ を用いてシミュレーションし、 それが連続性等の評価に及ぼす影響を明らかにしている ${ }^{3) 4) 。 そ の ~}$ 結果、「連続性」「整然性」には建物高さの標準偏差が、「開放感」に は建物高さの平均が影響していることが明らかとなった。

恒松、船越、積田らは街路景観の「ゆらぎ」に着目した研究を行

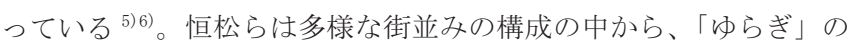
要因となる物理量変化を「ゆらぎ要素」として抽出し、「ゆらぎ度」 という尺度を定義して街並夕の統一感と多様性の関係を明らかにし ている。さらに、心理量分析を行うことで、街並みの心理評価とゆ らぎの心理評価との関係を明らかにしている。その結果、垂直方向 のゆらぎ度が小さいほど街路全体に「統一性」や「連続性」を生む ことが明らかとなった。

小泉、岸本らは街路景観の独自性に着目した研究を行っている ${ }^{778)}$ 小泉らはVR システムを用いた評価実験を行い、建物形態の変化に伴 う街路の印象や、建築ファサードと街路景観の印象との関係につい て研究を行っている。
* 慶應義塾大学大学院理工学研究科 修士課程

** 慶應義塾大学理工学部システムデザイン工学科 准教授・博士 (工学)
Graduate Student, Graduate School of Sci. \& Tech., Keio Univ.

Assoc. Prof., Dept. of System Design Eng., Faculty of Sci. \& Tech., Keio Univ., Dr. Eng. 
銀座中央通りを対象とした研究では、建物高さの変化に伴う街路 の印象と、特徴的なファサードとそれぞれのファサードを構成する 物理的構成要素の特徵について明らかにしている。その結果、高さ 規制の違いによる街路景観の印象の変化には低くスカイラインの統 一した建物高さの街路が必ずしも評価が良いわけではないことが明 らかとなった。

横浜元町通りを対象とした研究では、壁面後退の変化に伴う街路 の印象の変化と、街路の統一感と建物の独自性を両立させる物理的 構成要素の特徴について明らかにしている。その結果、独自性のあ るファサードは「繁華性」「印象度」が高く派手で賑やかなファサー ドであること、「好ましさ」「元町らしさ」が共に「情緒性」に大き な影響を受けていて、「繁華性」や「印象度」が高いほど元町らしさ が低下寸ることが明らかとなった。また、建物形態については過度 の統一を図るのではなく、変化のある現状の街路の評価が高いこと も明らかとなった。

街路景観の色の変化に着目した研究を行っているものとしては、 木多、奥、船越らの研究が挙げられる ${ }^{9)}$ 。木多らは、3D モデリング ソフトを用いて再現した幹線街路の色彩を操作し、建物群の壁面の 色彩の幅と「まとまり感」との関係を明らかにしている。また、色 彩の統一された街路景観における単一建物の色彩の突出とまとまり 感との関係についても明らかにしている。その結果、「まとまり感」 「好ましさ」「親しみ」の評価は色彩が均一に統一された景観よりも ある程度のバラツキがある景観の方が高いこと、「華やかさ」は彩度 のバラツキが大きくなるほど評価は高くなることが明らかとなった。 また、単一建物と周囲の建物の色差が大きいほど「まとまり感」「好 ましさ」は減少することが明らかとなった。

また、ファサードの構成要素と印象の関係について扱った論文と しては、A. E. Stamps の研究がある ${ }^{10)}$ 。A. E. Stamps は 1 建物の 画像に対し、セットバック、区切りの向き、開口の数、ファサード 面の凹凸に変化を与え、それらが建物の大きさの印象の評価に及ぼ 寸影響を明らかにしている。その結果、ファサードの大きさの印象 の評価にはセットバック、次いで開口部の数が大きな影響を与え、 区切りの向き、ファサード面の凹凸はほとんど影響を与えていない ことが明らかとなった。

CagriImanoglu は住宅ファサードの構成要素の量に変化を与えた 図を用いて印象評価を行うことで、住宅ファサードの複雑さが好ま しさや親しみといった印象に与える影響を明らかにしている ${ }^{11)}$ 。そ の結果、中程度の複雑さのファサードで好ましさは高くなり、それ は見覚えのあるものの中で最も複雑なものであることが明らかとな った。

これらの研究は、建物高さ、間口幅、セットバック、色彩といっ た、それぞれの形態的特徴やその変化が街路景観の印象に与える影 響について詳しく分析をしており、形態と評価との対応関係に関す る知見が得られている。しかし、それらの要素やその変化の程度が 組み合わさった時に、それぞれの要素がどの程度どのように印象の 評価に寄与しているか総合的な評価の構造を明らかにしたものは見 られない。また、それらの組み合わせから作りだされる望ましいフ アサードの形状について明らかにしているものもない。

そこで、本研究では集合住宅のファサードを取り上げ、その形態 的特徵と、建物の外観の印象と評価の関係を定量的に計測し、望ま
しいファサードの形状とその評価構造について明らかにする。

\section{2. 研究方法}

本研究では、統一的な街並みと沿道景観が形成されている幕張心゙ イタウンの集合住宅の景観を参考にして、異なる形態のファサード による沿道景観をシミュレーションして評価を行う。具体的に参考 にする建物は幕張ベイタウンのバレンタイン通りの建物である。建 物は 1 街区の 1 面に対して連続しているが、1 住戸の幅（約 $6.5 \mathrm{~m}$ ) を基準として、外装材の色に变化を加えて水平方向にファサードを 分節して見せている。バルコニーは壁面線の内側に設置されており、 フラットな壁面をなしている。高さは 6 階建てで一定であり、比較 的単純な形態をしている。

3D モデリングソフト注1)を用いて基準となる建物を含む街路の 3D モデルを作成した。外壁には参考にした建物の写真から外壁のテク スチャ画像を作成して使用した。図 1 に基準モデルを示す。

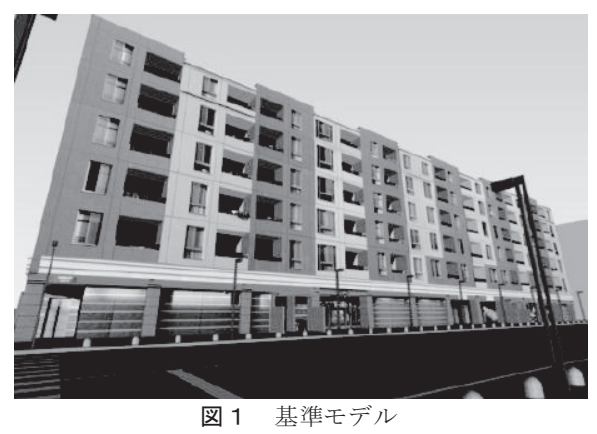

この基準モデルに対し、1. 分節幅の平均、2. 分節幅の差、3. 高さ の平均、4. 高さの差、5. セットバックさせる数、6. セットバックの 量に変化を与えた実験モデルを複数作成する。

1, 2 の分節幅というのは、外装材の色の変化によるファサードの 分節の幅を指し、これを取り上げたのは、基準モデルが住戸の間口 を 1 単位として外壁色を変えて分節を計っているためである。分節 をすることによって、ファサードに対して様々な印象の変化が生じ ると考えられる。 3,4 の建物高さと 5,6 のセットバックを取り上げ たのは、様々な場所で建物の高さと壁面線を揄えたり、セットバッ クさせることで建物の前面に空地を確保するなどのことが実際に行 われているためである。

こうして作成したモデルを用いて、分節幅の平均、分節幅の差、 高さの平均、高さの差、セットバックさせる数、セットバックの量 の違いが街路景観の印象に与える影響を明らかにしていく。

個々の属性に関して具体的に説明すると、まず分節幅の平均は 3 水準を用意し、水準 1 を住戸の幅と同じ $6.5 \mathrm{~m}$ 、水準 2 は 2 戸分の幅 の $13 \mathrm{~m}$ 、水準 3 は街区全体の大きさと同じ $78 \mathrm{~m}$ とした。3 水準では分 節が無い状態となる。

高さの平均は、水準 1 を $18.2 \mathrm{~m}$ とした。これは住居地域での高さ 制限によく用いられる $20 \mathrm{~m}$ に近い值をとったものである。水準 2 は $31.4 \mathrm{~m}$ とした。これは昭和 38 年 7 月の建基法施行令改正以前に高さ 制限に用いられていた $31 \mathrm{~m}$ に近い值をとったものである。水準 3 は $54.5 \mathrm{~m}$ で、これは代表的な商業地区である銀座で近年用いられてい 
る56mの高さ制限に近い值をとったものである。

分節幅の差および高さの差は街路内の建物のそれらの標準偏差の 值を基に水準を決定した。具体的には分節幅の差では水準 1 を標準 偏差が $0 \mathrm{~m}$ 、水準 2 を $3 \mathrm{~m}$ 、水準 3 を $9 \mathrm{~m}$ となるように設定した。高さ の差は水準 1 を標準偏差が $0 \mathrm{~m}$ 、水準 2 を $2 \mathrm{~m}$ 、水準 3 を $6 \mathrm{~m}$ とした。 これらはモデルを作成する際のバランスを考慮し、また、水準 2 と 水準 3 の值の比率が分節幅の差と高さの差で同じになるよう調整し た結果、最も収まりがよいと思われる值である。

セットバック数は水準 0 をセットバック無し、水準 1 で対象の建 物の $1 / 6$ 、水準 2 で $1 / 3$ 、水準 3 で $1 / 2$ の数の分節をセットバックさ せた。1/2 以上の分節をセットバックさせると、セットバックさせ た分節の壁面線の方が敷地境界線であるような印象を与えてしまう ため、最も高い水準である水準 3 を $1 / 2$ とした。水準 1 は 1 区画に 1 分節という場合を除くと、1 区画に 6 分節というのが最も少ない棟 数となるので、その際に 1 分節のみセットバックするようにしたも のである。水準 2 は水準 1 と水準 3 のちょうど中間である。

セットバック量は水準 0 をセットバック無し、水準 1 で $2 \mathrm{~m}$ 、水準 2 で $4 \mathrm{~m}$ 、水準 3 で $6 \mathrm{~m}$ とした。水準 3 の $6 \mathrm{~m}$ というのは、分節幅の平 均が最も小さいものが $6.5 \mathrm{~m}$ なので、それを超えてしまうと分節の間 にスペースができ、連続した街路景観ではなくなってしまうためで ある。また、この $6 \mathrm{~m}$ を 3 で割ると $2 \mathrm{~m}$ となり、水準 1 〜 3 で等間隔に なるので、水準 1 と 2 はそれぞれ $2 \mathrm{~m} 、 4 \mathrm{~m}$ とした。

これらの水準の組み合わせは、合計すると 490 通りとなるので、 全ての比較実験をすることは無理がある。そこで、実験計画法の直 行配列表注2)を利用して、表 2 に示寸 21 通りのモデルに絞った。

印象評価の被験者実験は以下のような手順で行っていく。前述の 21 通りの実験モデルに基準モデルを加えた 22 通りのモデルを用い た集合住宅の街路景観を 30 インチの大画面モニター（解像度 2560 ×1200pixe1）にそれぞれ見回しができる CG 画像で表示し注 3)、22 対の形容語対に対し、SD 法を用いたアンケートに答えてもらった。

被験者には30 インチモニタの前に正対して着座し、画面上に街路 景観を見てもらう。片手にマウスを持ち、それを前後左右に動かす ことによって、上下左右の方向の見回しができる。画面幅は約 $64 \mathrm{~cm}$ であり、画面から眼までの距離は約 $55 \mathrm{~cm}$ となるようにした。その時 の水平画角は約 $60^{\circ}$ となり、VR 空間上の画角もそれと同じになるよ うに設定した。日照環境は実験日に近い1月 13 日 AM10:00 の環境と した。

また、これらのモデルの画像をカラー印刷したカードを用いて好 ましいと思われる順に順位を付けてもらった。このカードは縦 $85 \mathrm{~mm}$ 、 横 $125 \mathrm{~mm}$ で、前の実験で見たモデルを区別できるように、ほぼ建物 の全体がカードに収まるように画角を超広角に設定した。

なお、被験者は建築系の学生 23 名、非建築系の学生 4 名の合計 27 名である。実験は 2012 年 1 月の第 2 週に行い、所要時間は 1 人 につき 40 分程度であった。

以下に実験の流れを示す。

(1) モデルを体験してもらう。この時、被験者にはマウス操作に より見回しを行い、モデル全体を見るようにしてもらった。

(2) SD 法のアンケートに答えてもらう。

(3) (1)、(2)を 22 通りのモデル全てで行う。モデルの提示順序は 前後の組み合わせによる影響が出ないようランダムに提示
した。

(4) 画像カードを用いて SD 法のアンケートで好ましさが同じだ ったモデル間でさらに好ましい順に順位を付けてもらう。

この形容語を用いた SD 法による実験を通して景観の評価構造を 明らかにする。次に総合的な評価值と SD 法から求められる各因子と の関係を重回帰分析によって明らかにし、さらに水準の異なる 21 通りのファサード形態に対する評価の因子得点と総合評価值を用い たコンジョイント分析によって、各水準の効用值および重みを算出 することによって、評価の構造と望ましいファサードの形態的特徴 の関係について明らかにする。最後に求めたコンジョイント分析の 評価パラメータ（重要度、部分効用値）を用いて、様々な評価を予 測するファサードを数理的に作成して提示できることを示し、集合 住宅による沿道景観と建物形態について分析・考察を行う。

\begin{tabular}{|c|c|c|}
\multicolumn{2}{|c|}{ 表1 } & 属性および水準 \\
\hline 属性 & 水準 & 数值 \\
\hline \multirow{3}{*}{ 分節幅の平均(W) } & 1 & $6.5 \mathrm{~m}$ \\
\cline { 2 - 3 } & 2 & $13 \mathrm{~m}$ \\
\cline { 2 - 3 } & 3 & $78 \mathrm{~m}$ \\
\hline \multirow{3}{*}{ 分節幅の差(W') } & 1 & 標準偏差:0m \\
\cline { 2 - 3 } & 2 & 標準偏差: $3 \mathrm{~m}$ \\
\cline { 2 - 3 } & 3 & 標準偏差:9m \\
\hline \multirow{3}{*}{ 高さの平均(H) } & 1 & $18.2 \mathrm{~m}$ \\
\cline { 2 - 3 } & 2 & $31.4 \mathrm{~m}$ \\
\cline { 2 - 3 } & 3 & $54.5 \mathrm{~m}$ \\
\hline \multirow{3}{*}{ 高さの差(H') } & 1 & 標隻偏差:0m \\
\cline { 2 - 3 } & 2 & 標準偏差:2m \\
\cline { 2 - 3 } & 3 & 標準偏差:6m \\
\hline \multirow{3}{*}{ セットバック数(S) } & 0 & セットバック無 \\
\cline { 2 - 3 } & 1 & 全体の $1 / 6$ \\
\cline { 2 - 3 } & 2 & 全体の $1 / 3$ \\
\cline { 2 - 3 } & 3 & 全体の $1 / 2$ \\
\hline \multirow{3}{*}{ セッバック量(S') } & 0 & セッバック無 \\
\cline { 2 - 3 } & 1 & $2 \mathrm{~m}$ \\
\cline { 2 - 3 } & 2 & $4 \mathrm{~m}$ \\
\cline { 2 - 3 } & 3 & $6 \mathrm{~m}$ \\
\hline
\end{tabular}

表2 モデルパターン

\begin{tabular}{|c|c|c|c|c|c|c|}
\hline モデル No & W & W' & H & H'$^{\prime}$ & S & S' \\
\hline 1 & 1 & 2 & 2 & 1 & 2 & 2 \\
\hline 2 & 1 & 1 & 3 & 2 & 1 & 2 \\
\hline 3 & 2 & 2 & 1 & 2 & 2 & 3 \\
\hline 4 & 1 & 3 & 1 & 3 & 2 & 1 \\
\hline 5 & 1 & 2 & 1 & 3 & 3 & 2 \\
\hline 6 & 1 & 2 & 3 & 1 & 3 & 1 \\
\hline 7 & 1 & 3 & 2 & 2 & 3 & 1 \\
\hline 8 & 2 & 3 & 1 & 1 & 1 & 2 \\
\hline 9 & 1 & 2 & 3 & 3 & 1 & 3 \\
\hline 10 & 2 & 1 & 3 & 3 & 2 & 1 \\
\hline 11 & 1 & 3 & 2 & 3 & 1 & 3 \\
\hline 12 & 1 & 3 & 3 & 2 & 2 & 2 \\
\hline 13 & 2 & 1 & 2 & 3 & 3 & 2 \\
\hline 14 & 1 & 1 & 2 & 1 & 2 & 3 \\
\hline 15 & 2 & 2 & 2 & 2 & 1 & 1 \\
\hline 16 & 1 & 1 & 1 & 1 & 1 & 1 \\
\hline 17 & 2 & 3 & 3 & 1 & 3 & 3 \\
\hline 18 & 1 & 1 & 1 & 2 & 3 & 3 \\
\hline 19 & 3 & 1 & 1 & 1 & 0 & 0 \\
\hline 20 & 3 & 1 & 2 & 1 & 0 & 0 \\
\hline 21 & 3 & 1 & 3 & 1 & 0 & 0 \\
\hline 基 & 1 & 1 & 1 & 1 & 0 & 0 \\
\hline
\end{tabular}




\section{3. 被験者実験結果とその分析}

\section{3-1. 街路景観の印象評価の構造分析}

街路景観の印象に関わる表 3 で示寸合計 21 の形容語対と「好まし い一好ましくない」の評価に関わる項目を加えた 22 の形容語対を用 いて SD 法による印象評価実験を行った。

まず 21 の形容語対の印象評価結果を用いて因子分析(バリマック ス法）を行った。形容語対を相関のあるもののグループに分類し、 それぞれの形容語対の持つ共通因子を読み取った。表 3 の色を変え た部分はその形容語を最も説明している因子を表す。ここから、こ の 3 つの因子を次のように解釈した。

$\left\{\begin{array}{l}\text { 因子 } 1 \rightarrow \text { 統一性因子: 空間の統一感、連続性を形容 } \\ \text { 因子 } 2 \rightarrow \text { 情緒性因子 : 空間の情緒感や美しさを形容 } \\ \text { 因子 } 3 \rightarrow \text { 密度性因子 : 空間の物的、心的な密度感を形容 }\end{array}\right.$

因子 1 は、「統一感のある一統一感のない」、「連続した一不連続な」など、 空間の統一感、連続性を形容しており統一性の因子といえる。因子 2 は「美しい一美しくない」、「賑やかな一寂しい」など空間の情緒 感や美しさを形容しており情緒性の因子といえる。因子 3 は、「開放 的な一圧迫感のある」といった物的な密度感や、「都会的な一田舎的 な」、「胆な一繊細な」、「高級感のある一高級感のない」などの都 会的で高級感のある心的な密度感を形容しており密度性の因子とい える。

さらに、これらの 3 因子を独立変数に、「好ましい一好ましくない」 を従属変数にして重回帰分析を行った。その結果を表 4 に示す。

表 4 をみると、好ましさに最も影響を与えるのは情緒性であるこ とが分かる。また、統一性は好ましさにあまり影響を与えないと言 える。

表3 街路の評価に対する因子負荷行列

\begin{tabular}{|c|c|c|c|c|}
\hline & & 統一性 & 情緒性 & 密度性 \\
\hline \multicolumn{2}{|c|}{ 統一感のある一統一感のない } & 0.855 & -0.033 & 0.265 \\
\hline \multicolumn{2}{|c|}{$\begin{array}{l}\text { 連続した一不連続な } \\
\end{array}$} & 0.846 & -0.153 & 0.189 \\
\hline \multicolumn{2}{|c|}{ 調和した一不調和な } & 0.786 & 0.174 & 0.107 \\
\hline \multicolumn{2}{|c|}{ まとまりのある一まとまりのない } & 0.769 & 0.057 & 0.212 \\
\hline \multicolumn{2}{|c|}{$\begin{array}{l}\text { 複雑な一単純な } \\
\end{array}$} & -0.752 & 0.313 & 0.096 \\
\hline \multicolumn{2}{|c|}{ 個性的な一平凡な } & -0.656 & 0.366 & 0.176 \\
\hline \multicolumn{2}{|c|}{ 見慣れた一見慣れない } & 0.641 & -0.019 & -0.148 \\
\hline \multicolumn{2}{|c|}{ 落ち着きのある一落ち着きのない } & 0.631 & -0.026 & -0.120 \\
\hline \multicolumn{2}{|c|}{$\begin{array}{c}\text { 派手な一地味な } \\
\end{array}$} & -0.519 & 0.329 & 0.436 \\
\hline \multicolumn{2}{|c|}{ 印象に残る一印象に残らない } & -0.503 & 0.367 & 0.347 \\
\hline \multicolumn{2}{|c|}{ 楽しい—つまらない } & -0.202 & 0.777 & 0.048 \\
\hline \multicolumn{2}{|c|}{ 快適な一不快な } & 0.409 & 0.689 & -0.285 \\
\hline \multicolumn{2}{|c|}{ 美しい一美しくない } & 0.380 & 0.678 & -0.003 \\
\hline \multicolumn{2}{|c|}{ 洗練された一野暮な } & 0.181 & 0.653 & 0.306 \\
\hline \multicolumn{2}{|c|}{ 賑やかな一寂しい } & -0.179 & 0.556 & 0.131 \\
\hline \multicolumn{2}{|c|}{ 親しみのある一親しみのない } & 0.448 & 0.550 & -0.262 \\
\hline \multicolumn{2}{|c|}{ 開放的な一圧迫感のある } & 0.050 & 0.494 & -0.560 \\
\hline \multicolumn{2}{|c|}{ 都会的な一田舎的な } & 0.024 & 0.146 & 0.522 \\
\hline \multicolumn{2}{|c|}{ 高級感のある一高級感のない } & 0.174 & 0.446 & 0.478 \\
\hline \multicolumn{2}{|c|}{$\begin{array}{c}\text { 大胆な一繊細な } \\
\end{array}$} & -0.346 & -0.213 & 0.422 \\
\hline \multicolumn{2}{|c|}{ 生活感のある生活感のない } & 0.281 & 0.271 & -0.320 \\
\hline \multirow{2}{*}{ 初期の固有值 } & 分散 (\%) & 30.003 & 19.729 & 11.250 \\
\hline & 累積 (\%) & 30.003 & 49.732 & 60.983 \\
\hline \multirow{2}{*}{ 抽出後の負荷量平方和 } & 分散 (\%) & 27.788 & 17.583 & 9.086 \\
\hline & 累積 (\%) & 27.788 & 45.372 & 54.457 \\
\hline 妥当性 & 0.890 & & & \\
\hline
\end{tabular}

表4 好ましさを目的変数とした重回帰分析

\begin{tabular}{|c|c|c|c|}
\hline & 偏回帰係数 & 標準偏回㷌係数 & 単相関係数 \\
\hline 統一性 & 0.976 & 0.149 & 0.159 \\
\hline 情緒性 & 3.739 & 0.547 & 0.568 \\
\hline 密度性 & 2.203 & 0.320 & 0.349 \\
\cline { 1 - 2 } 定数 & 11.500 & \multicolumn{3}{|}{} \\
\cline { 1 - 2 } 重相関係数 & 0.668 & \multicolumn{3}{|}{} \\
\cline { 1 - 2 } (2 乗) & 0.446 & \multicolumn{3}{|l}{} \\
\cline { 1 - 2 }
\end{tabular}

\section{3-2. 建物形態の変化が統一性の印象の評価に与える影響}

因子分析から得られた統一性の尺度と建物形態の関係についてコ ンジョイント分析を行い、どの形態的特徴が統一性にどの程度影響 しているかを分析した。その結果を表 5 に示す。表 5 をみると、高 さの差の重要度が最も高く顕著であり、統一性には高さの差が最も 影響しており、高さの差が少ない街路ほど統一性は増すことが分か る。また、セットバックも高さの差ほど影響は大きくないが、統一 性に影響を与えており、セットバックが無いものが最も統一性が高 く、セットバックの数や量が増えるにつれ統一性は低くなる。

\section{3-3. 建物形態の変化が情緒性の印象に与える影響}

情緒性に関してもコンジョイント分析を行った。その結果を表 6 に示す。表 6 をみると、情緒性に最も大きく影響を与えるのは高さ の平均であることが分かる。街路の建物の高さの平均が低くなるほ ど情緒性は増すといえる。また、高さの平均ほどではないが、分節 幅の平均も情緒性に影響を与えている。分節幅の平均は $13 \mathrm{~m}$ の場合 に最も評価が高く、 $6.5 \mathrm{~m}$ や $78 \mathrm{~m}$ の場合にはマイナスの評価となっ てしまう。そのため、分節幅の平均は小さすぎても大きすぎても評 価が下がってしまう。つまり、6.5mや $78 \mathrm{~m}$ の間に適度な分節幅が あると考えられる。

\section{3-4. 建物形態の変化が密度性の評価に与える影響}

密度性に関してもコンジョイント分析を行った。その結果を表 7 に示寸。表 7 を夕ると、密度性は分節幅の平均や高さの平均が大き く影響しており、分節幅が狭くなるほど、また建物の高さが大きく なるほど密度性は増すことがわかる。また、密度性には高さの差も 関係しており、高さの差は大きすぎても小さすぎても密度性は下が ってしまう。

\section{4. 印象の評価を反映した街路空間の構築}

\section{4-1. 実験モデルにおける印象の評価}

以下の式は表4 に示した重回帰分析と表 5〜 7 に示したコンジョイ ント分析の結果から好ましさの評価值を求めたものである。

好ましさ $\mathrm{L}=0.976 \mathrm{U}+3.739 \mathrm{E}+2.203 \mathrm{D}$

$\mathrm{W}_{\mathrm{a}}$ : 水準 $\mathrm{a}$ のときの分節幅の平均の各因子における部分効用値 $\mathrm{W}^{\prime}{ }_{\mathrm{b}}$ : 水準 $\mathrm{b}$ のときの分節幅の差の各因子における部分効用值 
表5 統一性に関するコンジョイント分析

\begin{tabular}{|c|c|c|c|c|c|c|}
\hline 要素 & 水準 & 部分効用值 & - & + & 有意確率 & 重要度 \\
\hline \multirow{3}{*}{$\begin{array}{l}\text { 分節幅 } \\
\text { の平均 }\end{array}$} & 1 & -0.260 & & & 0.000 & \multirow{3}{*}{0.116} \\
\hline & 2 & 0.161 & & & & \\
\hline & 3 & 0.099 & & & 0.676 & \\
\hline \multirow{3}{*}{$\begin{array}{c}\text { 分節幅 } \\
\text { の差 }\end{array}$} & 1 & -0.025 & & & 0.678 & \multirow{3}{*}{0.013} \\
\hline & 2 & 0.002 & & & & \\
\hline & 3 & 0.023 & & & 0.754 & \\
\hline \multirow{3}{*}{$\begin{array}{c}\text { 高さ } \\
\text { の平均 }\end{array}$} & 1 & -0.165 & & & 0.068 & \multirow{3}{*}{0.105} \\
\hline & 2 & -0.053 & & & & \\
\hline & 3 & 0.218 & & & 0.000 & \\
\hline \multirow{3}{*}{$\begin{array}{l}\text { 高さ } \\
\text { の差 }\end{array}$} & 1 & 0.643 & & & 0.000 & \multirow{3}{*}{0.354} \\
\hline & 2 & 0.001 & & & & \\
\hline & 3 & -0.645 & & & 0.000 & \\
\hline \multirow{2}{*}{$\begin{array}{c}\text { セットバック } \\
\text { の有無 }\end{array}$} & $\begin{array}{l}\text { 無 } \\
\end{array}$ & 0.271 & & & 0.000 & \multirow{2}{*}{0.1492} \\
\hline & 有 & -0.271 & & & & \\
\hline \multirow{3}{*}{$\begin{array}{c}\text { セットバック } \\
\text { させる数 }\end{array}$} & 1 & 0.249 & & & 0.000 & \multirow{3}{*}{0.1295} \\
\hline & 2 & -0.027 & & & & \\
\hline & 3 & -0.222 & & & 0.003 & \\
\hline \multirow{3}{*}{$\begin{array}{c}\text { セットバック } \\
\text { の量 }\end{array}$} & 1 & 0.222 & & & 0.006 & \multirow{3}{*}{0.1333} \\
\hline & 2 & 0.040 & & & & \\
\hline & 3 & -0.263 & & & 0.000 & \\
\hline 重相関係数 & 0.794 & & & & & \\
\hline （2 乗） & 0.631 & & & & & \\
\hline
\end{tabular}

表6 情緒性に関するコンジョイント分析

\begin{tabular}{|c|c|c|c|c|c|c|}
\hline 要素 & 水準 & 部分効用值 & - & + & 有意確率 & 重要度 \\
\hline \multirow{3}{*}{$\begin{array}{l}\text { 分節幅 } \\
\text { の平均 }\end{array}$} & 1 & -0.040 & & & 0.000 & \multirow{3}{*}{0.221} \\
\hline & 2 & 0.325 & & & & \\
\hline & 3 & -0.285 & & & 0.001 & \\
\hline \multirow{3}{*}{$\begin{array}{c}\text { 分節幅 } \\
\text { の差 }\end{array}$} & 1 & 0.092 & & & 0.254 & \multirow{3}{*}{0.068} \\
\hline & 2 & 0.003 & & & & \\
\hline & 3 & -0.095 & & & 0.211 & \\
\hline \multirow{3}{*}{$\begin{array}{l}\text { 高さ } \\
\text { の平均 }\end{array}$} & 1 & 0.647 & & & 0.000 & \multirow{3}{*}{0.498} \\
\hline & 2 & 0.080 & & & & \\
\hline & 3 & -0.727 & & & 0.000 & \\
\hline \multirow{3}{*}{$\begin{array}{l}\text { 高さ } \\
\text { の差 }\end{array}$} & 1 & 0.051 & & & 0.136 & \multirow{3}{*}{0.139} \\
\hline & 2 & 0.167 & & & & \\
\hline & 3 & -0.217 & & & 0.000 & \\
\hline \multirow{2}{*}{$\begin{array}{c}\text { セットバック } \\
\text { の有無 }\end{array}$} & $\begin{array}{l}\text { 無 } \\
\end{array}$ & -0.039 & & & 0.647 & \multirow{2}{*}{0.028} \\
\hline & 有 & 0.039 & & & & \\
\hline \multirow{3}{*}{$\begin{array}{c}\text { セットバック } \\
\text { させる数 }\end{array}$} & 1 & 0.032 & & & 0.846 & \multirow{3}{*}{0.030} \\
\hline & 2 & 0.017 & & & & \\
\hline & 3 & -0.049 & & & 0.394 & \\
\hline \multirow{3}{*}{$\begin{array}{c}\text { セットバック } \\
\text { の量 }\end{array}$} & 1 & 0.009 & & & 0.915 & \multirow{3}{*}{0.016} \\
\hline & 2 & 0.018 & & & & \\
\hline & 3 & -0.027 & & & 0.569 & \\
\hline 重相関係数 & 0.667 & & & & & \\
\hline (2 乗) & 0.444 & & & & & \\
\hline
\end{tabular}

表7 密度性に関するコンジョイント分析

\begin{tabular}{|c|c|c|c|c|c|c|}
\hline 要素 & 水準 & 部分効用値 & - & + & 有意確率 & 重要度 \\
\hline \multirow{3}{*}{$\begin{array}{l}\text { 分節幅 } \\
\text { の平均 }\end{array}$} & 1 & 0.223 & & & 0.023 & \multirow{3}{*}{0.285} \\
\hline & 2 & 0.026 & & & & \\
\hline & 3 & -0.249 & & & 0.217 & \\
\hline \multirow{3}{*}{$\begin{array}{c}\text { 分節幅 } \\
\text { の差 }\end{array}$} & 1 & 0.058 & & & 0.304 & \multirow{3}{*}{0.062} \\
\hline & 2 & -0.044 & & & & \\
\hline & 3 & -0.015 & & & 0.769 & \\
\hline \multirow{3}{*}{$\begin{array}{l}\text { 高さ } \\
\text { の平均 }\end{array}$} & 1 & -0.258 & & & 0.001 & \multirow{3}{*}{0.284} \\
\hline & 2 & 0.044 & & & & \\
\hline & 3 & 0.213 & & & 0.067 & \\
\hline \multirow{3}{*}{$\begin{array}{l}\text { 高さ } \\
\text { の差 }\end{array}$} & 1 & -0.038 & & & 0.029 & \multirow{3}{*}{0.193} \\
\hline & 2 & 0.179 & & & & \\
\hline & 3 & -0.141 & & & 0.001 & \\
\hline \multirow{2}{*}{$\begin{array}{c}\text { セットバック } \\
\text { の有無 }\end{array}$} & \begin{tabular}{|c|c|} 
無 \\
\end{tabular} & 0.069 & & & 0.530 & \multirow{2}{*}{0.083} \\
\hline & 有 & -0.069 & & & & \\
\hline \multirow{3}{*}{$\begin{array}{c}\text { セットバック } \\
\text { させる数 }\end{array}$} & 1 & 0.052 & & & 0.250 & \multirow{3}{*}{0.069} \\
\hline & 2 & -0.062 & & & & \\
\hline & 3 & 0.010 & & & 0.467 & \\
\hline \multirow{3}{*}{$\begin{array}{c}\text { セットバック } \\
\text { の量 }\end{array}$} & 1 & -0.013 & & & 0.697 & \multirow{3}{*}{0.023} \\
\hline & 2 & 0.025 & & & & \\
\hline & 3 & -0.012 & & & 0.708 & \\
\hline 重相関係数 & 0.289 & & & & & \\
\hline (2 乗) & 0.083 & & & & & \\
\hline
\end{tabular}

$\mathrm{H}_{\mathrm{c}}$ : 水準 $\mathrm{c}$ のさきの高さの平均の各因子における部分効用值 $\mathrm{H}^{\prime}{ }_{\mathrm{d}}$ : 水準 $\mathrm{d}$ のときの高さの差の各因子における部分効用值 $\mathrm{S}_{\mathrm{e}}$ : セットバックが有 or 無のときの各因子における部分効用值 この式を用いて好ましさの最大值を求めると、分節幅の平均、分節 幅の差、高さの平均、高さの差、セットバックの有無の順に水準が $(2,1,1,1$, 無) の組合せのモデルが最も好ましい組合せのモデルであ ることが分かる。このモデル画像を図 2 に示す。図 2 をみると、最 も好ましい街路は分節幅が中程度で、スカイラインや壁面線が揃つ ているといった特徴を持つと考えられる。

また、好ましさが最も低いモデルは (1, 3, 3, 有)の組み合わせのモ デルと推測される。しかし、実験で用いたモデルにはセットバック 数とセットバック量にも変化を加えている。そこで、セットバック 数とセットバック量を加味した下記の関係式を用いることで、分節 幅の平均、分節幅の差、高さの平均、高さの差、セットバック数、 セットバック量の順に水準が $(1,1,1,3,3,3)$ の組み合わせが最も好 ましさが低いと考えられる。

好ましさ $\mathrm{L}^{\prime}=0.976 \mathrm{U}^{\prime}+3.739 \mathrm{E}^{\prime}+2.203 \mathrm{D}^{\prime}$

( 統一性 $\mathrm{U}^{\prime}=0.116 \mathrm{~W}_{\mathrm{U}^{\prime} \mathrm{a}}+0.013 \mathrm{~W}_{\mathrm{U}^{\prime} \mathrm{b}}+0.105 \mathrm{H}_{\mathrm{U}^{\prime} \mathrm{c}}+0.354 \mathrm{H}^{\prime}$

$$
\begin{aligned}
& +0.130 \mathrm{~S}_{\mathrm{U}^{\prime} \mathrm{f}}^{\prime}+0.133 \mathrm{~S}_{\mathrm{U} / \mathrm{g}}^{\prime} \\
& \left\{\text { 情緒性 } \mathrm{E}^{\prime}=0.221 \mathrm{~W}_{\mathrm{E}^{\prime} \mathrm{a}}+0.068 \mathrm{~W}_{\mathrm{E}^{\prime} \mathrm{b}}+0.498 \mathrm{H}_{\mathrm{E}^{\prime} \mathrm{c}}+0.139 \mathrm{H}^{\prime}{ }_{\mathrm{E}^{\prime} \mathrm{d}}\right. \\
& +0.030 \mathrm{~S}_{\mathrm{U}^{\prime} \mathrm{f}}^{\prime}+0.016 \mathrm{~S}_{\mathrm{U} / \mathrm{g}}^{\prime \prime} \\
& \text { 密度性 } \mathrm{D}^{\prime}=0.285 \mathrm{~W}_{\mathrm{D}^{\prime} \mathrm{a}}+0.062 \mathrm{~W}_{\mathrm{D}^{\prime} \mathrm{b}}^{\prime}+0.284 \mathrm{H}_{\mathrm{D}^{\prime} \mathrm{c}}+0.193 \mathrm{H}_{\mathrm{D}^{\prime} \mathrm{d}}^{\prime} \\
& +0.069 \mathrm{~S}_{\mathrm{U}^{\prime} \mathrm{f}}^{\prime}+0.023 \mathrm{~S}_{\mathrm{U} / \mathrm{g}}^{\prime \prime}
\end{aligned}
$$

$\mathrm{S}_{\mathrm{f}}{ }_{\mathrm{f}}$ : 水準 $\mathrm{f}$ のときセットバック数の各因子における部分効用值 $\mathrm{S}_{\mathrm{g}}$ : 水準 $\mathrm{g}$ のときのセットバック量の各因子における部分効用值 このモデル画像を図 3 に示す。図 3 から最も好ましくない街路は、 好ましい街路とは逆で、スカイラインや壁面線が大きく乱れている といった特徵を持つと考えられる。また、分節幅も狭い。

次に、統一性、情緒性、密度性、それぞれの因子について最高の ファサードと最低のファサードを比較する。

統一性が最も高いモデルは、( $2,3,3,1$, 無)の組み合わせであると 推測される。このモデルの画像を図 4 に示す。また、統一性が最も 低いモデルは、(1, 1, 1, 3, 有)の組み合わせである。これも好ましさ の最も低いモデルと同様にセットバック数および量の影響を加味す ると、(1, 1, 1, 3, 3, 3)の組み合わせであると推測され、好ましさの最 も低いモデルと同じという結果となった。眓 4 をみると、統一性の 最も高いモデルは高さが高く、スカイラインや壁面線が揃っている という特徴を持つと考えられる。

情緒性に関しては、(2, 1, 1, 2, 有)の組み合わせが最も高い值を取 る。これもセットバックの数と量の影響を加味すると $(2,1,1,2,1,2)$ の組み合わせが最も情緒性が高いと考えられる。このモデル画像を 図 5 に示す。図 5 をみると、情緒性の最も高いモデルは高さの平均 が低く、分節幅は中程度であるといった特徵を持つと考えられる。

また、情緒性の最も低い組み合わせは（3, 1, 3, 1, 無)の組み合わせ であると推測される。この組み合わせは実験モデルのMode121 と同 じである。このモデル画像を図 6 に示す。眓 6 をみると、情緒性の 最も低いモデルは、分節幅が非常に大きく、高さの平均も高いとい つた特徴を持つと考えられる。

密度性に関しては、(1, 1, 3, 2, 無)の組み合わせが最も密度性が高 いと推測される。このモデル画像を図 7 に示す。図 7 から、密度性 


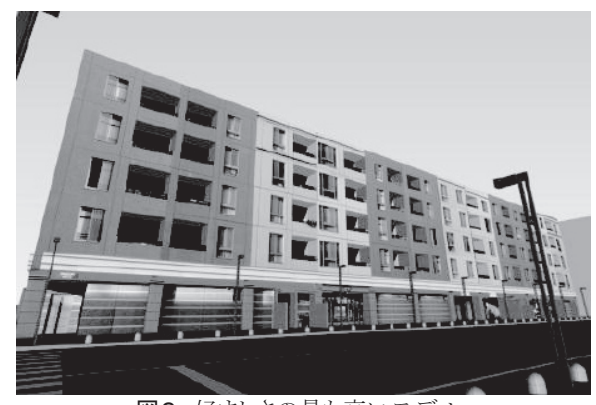

図2 好ましさの最も高いモデル

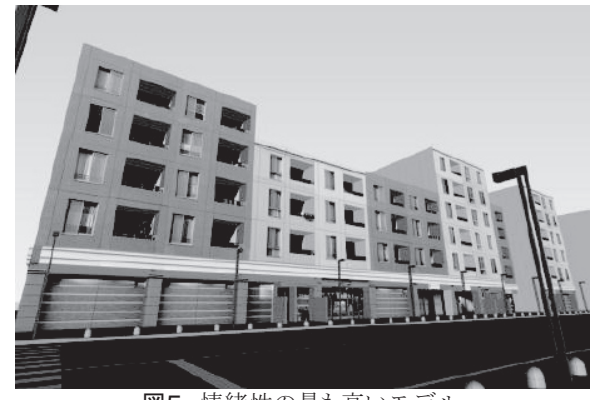

図5 情緒性の最も高いモデル

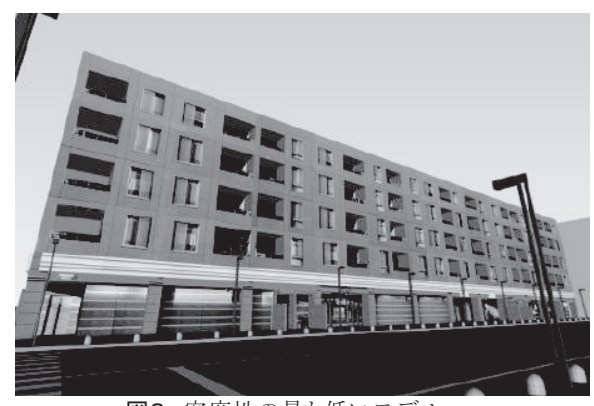

図8 密度性の最も低いモデル

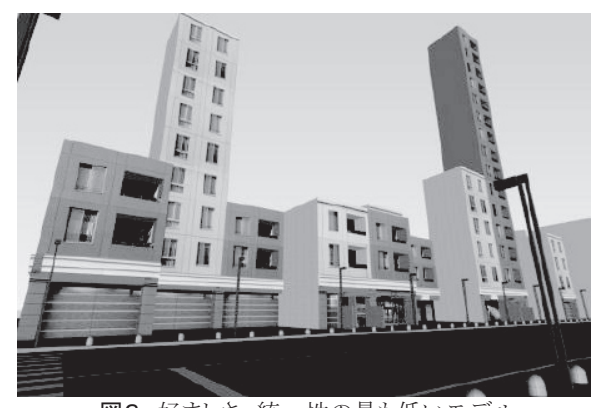

図3 好ましさ、統一性の最も低いモデル

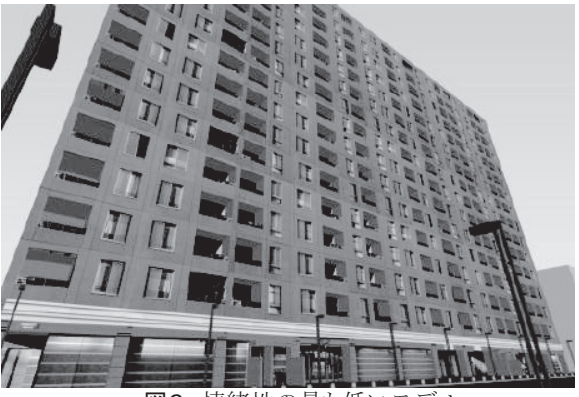

図6 情緒性の最も低いモデル

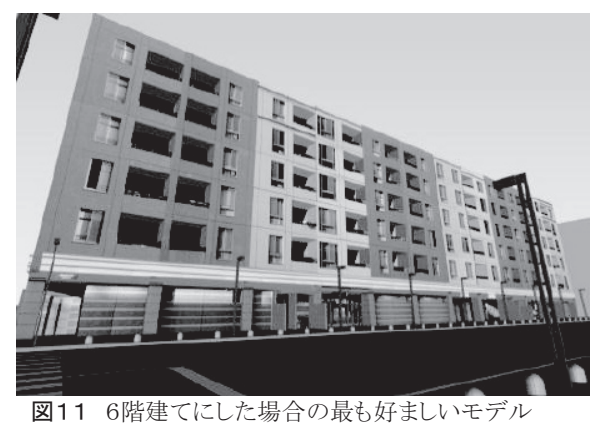

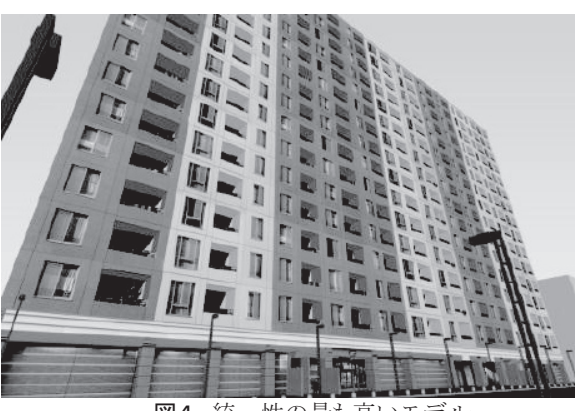

図4 統一性の最も高いモデル

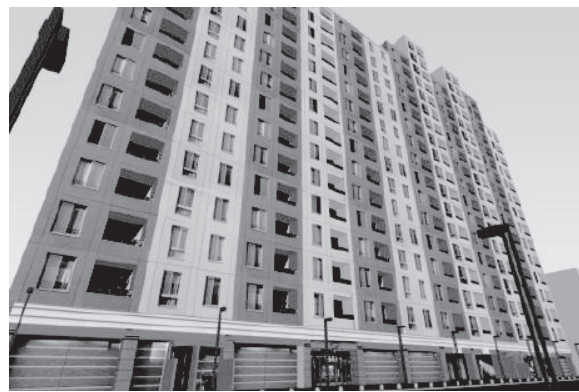

図7 密度性の最も高いモデル
の最も高いモデルは高さの平均が高く、分節幅が狭いといった特徵 を持つと考えられる。

また、密度性の最も低いモデルは $(3,1,1,1$, 無)であると推測され る。これは実験モデルの Mode119 と同じである。このモデル画像を 図 8 に示す。図 8 から密度性の最も低いモデルは分節幅が非常に広 く、高さが低いといった特徵を持つと考えられる。

表 8 は、これらの予測式により求めた各因子および好ましさの得 点と、被験者による評価実験の結果による因子得点平均との相関係 数を求めた結果である。これらを見ると予測式による得点と実験結 果による得点の間には強い相関がみられており、予測式による結果 は、人の印象評価に対して一定の説明力があるといえる。

表 8

\begin{tabular}{|c|c|c|}
\hline & 相関係数 & 有意確率 \\
\hline 統一性 & 0.777 & 0.000 \\
\hline 情緒性 & 0.907 & 0.000 \\
\hline 密度性 & 0.743 & 0.000 \\
\hline 好ましさ & 0.814 & 0.000 \\
\hline
\end{tabular}

\section{4-2．望ましいファサード形状の考察}

図 10 は各モデルの好ましさの評価の全被験者の平均点を示した ものである。この結果から、最も好ましく評価されたモデルはモデ
ル 16 で、次がモデル 3 である。これらのモデルの特徴は、高さの平 均が最も低い水準で、セットバック数も水準 1 と 2 で比較的低い水 準であることである。コンジョイント分析の結果より高さの平均と セットバックは情緒性に寄与しており、また、情緒性は最も好まし さに影響を与えるので、この結果は第 3 章の結果と一致している。

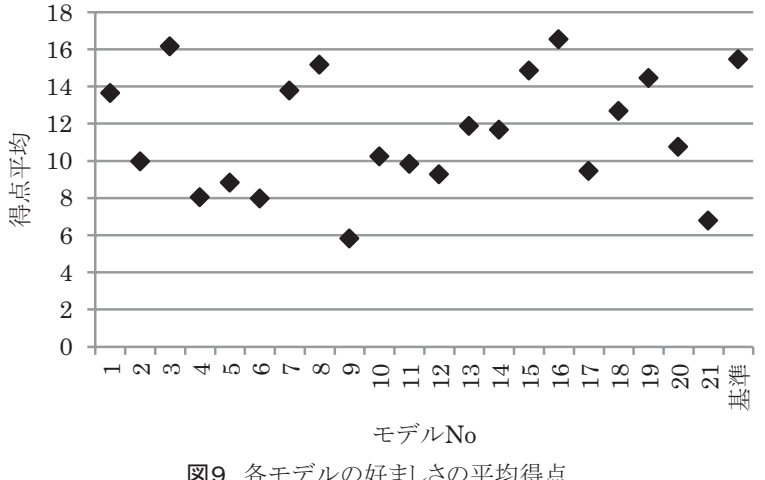

また、表 9 は 4-1 の好ましさと各要素との関係式に 3 のコンジョ イント分析の結果から好ましさに対する各要素の部分効用值を求め たものである。また、図 10 は各要素と好ましさの関係における重 要度を示したものである。これら表 9 および図 10 から以下のこと 
がいえる。

(1)図 10 より好ましさには分節幅の平均、高さの平均、高さの差 が大きく影響しており、その影響の度合いは高さの平均、分節幅の 平均、高さの差の順に大きい、(2)表 9 上り好ましさと分節幅の平均 との関係において、分節幅が中程度の水準のとき、最も好ましさが 大きくなる、(3)好ましさと高さの平均との関係においては、高さの 平均が低くなるほど好ましさが高くなる、(4)好ましさと高さの差と の関係においては、高さの差が中程度のとき、最も好ましさが大き くなる。

これらのことから、好ましい街路空間は、高さの平均が低く、分 節幅の平均や高さの差が中程度のものであることが分かる。

ところで、最も好ましいモデルは 5 階建てであったのに対し、基 準モデルは 6 階建てである。そこで、この違いの影響についても考 察できるよう、最も好ましいモデルを 6 階建てに変えたモデル画像 を図 11 に示す。ここで、表 9 を見ると高さの平均が低くなるほど 好ましさは高くなることが分かる。つまり、建物の高さは少しでも 低くしたほうが良いと考えられる。

ここまでの全ての結果を踏まえると、望ましいファサードを構築 するには、分節幅を $13 \mathrm{~m}$ 程度にし、高さをできるだけ抑えることが 最も効果的だといえる。

表 9 好ましさと各要素との関係

\begin{tabular}{|c|c|c|c|c|c|}
\hline 要素 & 水準 & 部分効用值 & - & + & 重要度 \\
\hline \multirow{3}{*}{$\begin{array}{l}\text { 分節幅 } \\
\text { の平均 }\end{array}$} & 1 & 0.088 & & & \multirow{3}{*}{1.567} \\
\hline & 2 & 1.429 & & & \\
\hline & 3 & -1.517 & & & \\
\hline \multirow{3}{*}{$\begin{array}{c}\text { 分節幅 } \\
\text { の差 }\end{array}$} & 1 & 0.447 & & & \multirow{3}{*}{0.401} \\
\hline & 2 & -0.084 & & & \\
\hline & 3 & -0.363 & & & \\
\hline \multirow{3}{*}{$\begin{array}{l}\text { 高さの } \\
\text { 平均 }\end{array}$} & 1 & 1.690 & & & \multirow{3}{*}{2.592} \\
\hline & 2 & 0.347 & & & \\
\hline & 3 & -2.037 & & & \\
\hline \multirow{3}{*}{$\begin{array}{l}\text { 高さの } \\
\text { 差 }\end{array}$} & 1 & 0.735 & & & \multirow{3}{*}{1.292} \\
\hline & 2 & 1.018 & & & \\
\hline & 3 & -1.753 & & & \\
\hline \multirow{2}{*}{$\begin{array}{c}\text { セットバック } \\
\text { の有無 }\end{array}$} & $\begin{array}{l}\text { 無 } \\
\end{array}$ & 0.270 & & & \multirow{2}{*}{0.435} \\
\hline & 有 & -0.270 & & & \\
\hline \multirow{3}{*}{$\begin{array}{c}\text { セットバック } \\
\text { させる数 }\end{array}$} & 1 & 0.478 & & & \multirow{3}{*}{0.389} \\
\hline & 2 & -0.099 & & & \\
\hline & 3 & -0.379 & & & \\
\hline \multirow{3}{*}{$\begin{array}{c}\text { セットバック } \\
\text { の量 }\end{array}$} & 1 & 0.222 & & & \multirow[b]{2}{*}{0.242} \\
\hline & 2 & 0.161 & & & \\
\hline & 3 & -0.383 & & & \\
\hline
\end{tabular}

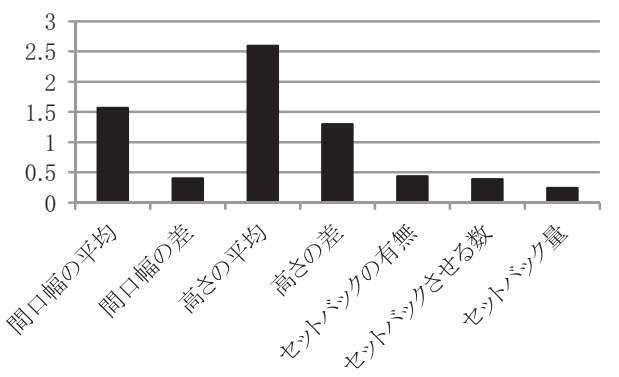

図10 好ましさと各要素の関係における重要度

\section{5. 結論および今後の課題}

本研究では 3D モデリングソフトにより再現した街路空間に分節 幅の平均、分節幅の差、高さの平均、高さの差、セットバック数、 セットバック量に変化を加え、それを被験者に体験してもらうこと で、分節幅の平均、分節幅の差、高さの平均、高さの差、セットバ ック数、セットバック量と、統一性、情緒性、密度性、好ましさと いった街路景観の印象との関係を明らかにした。

また、これらの分析の結果から統一性、情緒性、密度性、好まし さと分節幅の平均、分節幅の差、高さの平均、高さの差、セットバ ック数、セットバック量の関係式を導き出すことによって、意図的 に印象を操作した街路空間を再現できることを示すことができた。

街路景観の印象の評価にはこれら建物の形態やセットバックだけ でなく、街路の道幅、バルコニーの形態、壁面の素材や色、人通り の量などの他の様々な要因も影響していると考えられる。そこで今 後は、本研究で取り扱った建物形態以外による影響も考慮に入れる 必要がある。

\section{注}

注 1) SketchUp 8 在使用

注 2) 直交配列表とは「因子のすべてのペアに対して因子の水準について考え られる処理組み合わせが同数回現われるような処理組み合わせの集合 (JISより)」と定義される。これを用いることで、実験回数を隇らし効 率的に実験を行うことができる。本研究では、統計解析ソフトSPSS を用 いてこの直交配列表を作成した。

注 3) B-Walker（Alphacox 社製）を使用している。B-Walker はSketchUP で作 成したモデルの空間をウォークスルーや見回しができ、天候や時刻など も設定ができる簡易な VR シミュレーションソフトである。

\section{参考文献}

1) 篠原修, 屋代雅充 : 街路景観のまとまりに及ぼす沿道建物の効果に関する計 量心理学的研究, 土木学会論文集, No. 353/IV-2, pp. 131-138, 1985.1

2) 奥俊信, 紙野桂人, 舟橋國男, 小浦久子, 木多道宏 : 1 建物の形態変化が景観 の連続性評価に与える影響一ステレオグラムを適用した実験一, 日本都市 計画学会学術研究論文集, No. 30, pp295-300, 1995. 11

3) 鄭在熙, 奥俊信, 舟橋國男, 小浦久子, 木多道宏 : バーチャルリアリティを用 いた街路景観の移行変化と評価に関寸る研究：一建物の高さ及びセット バックの変化と連続性等の評価の関係一, 日本建築学会計画系論文集, No503, pp163-169, 1998.1

4) 鄭在熙, 中村佳之, 奥俊信, 舟橋國男, 鈴木毅, 小浦久子,木多道宏 : 高層階を 形態コントロールした場合の景観の移行変化と評価に関する研究ーバー チャルリアリティを用いた街路景観の移行変化と評価に関する研究その 2 一, 日本建築学会計画系論文集, No522, pp231-237, 1999.8

5) 恒松良純，船越䡓，積田洋：街並みの「ゆらぎ」の物理量分析一街路景観 の「ゆらぎ」に関する研究（その1）一, 日本建築学会計画系論文集, №542, pp137-144, 2001. 4

6) 恒松良純, 船越徹, 積田洋 : 街並みの「ゆらぎ」の物理量分析一街路景観 の「ゆらぎ」に関する研究（その2）一, 日本建築学会計画系論文 集, No597, pp45-52, 2005. 11

7) 小泉光司, 岸本達也 : 銀座中央通りにおける建物高さと建物ファサードに着 目した景観分析一個性的な街路景観創出を目的としたVRを用いた景観分 析(その 1) -, 日本建築学会計画系論文集, No613, pp151-158, 2007. 3

8) 小泉光司, 岸本達也, 小場則夫 : 街路の統一感と建物の独自性に着目した横 浜元町通りにおける景観分析一個性的な街路景観創出を目的とした VRを 用いた景観分析（その3) - , 日本建築学会計画系論文集， No636, pp393-400, 2009. 2

9) 木多道宏, 奥俊信, 舟橋國男, 鈴木毅, 小浦久子 : 街路景観における色彩の心 理効果一連続する建物群の基調色および単一建物の強調色の変化と「まと まり」評価等との関係，日本建築学会計画系論文 
集, No522, pp239-246, 1999. 8

10)A E Stamps III : Measure of architectural mass: from vague impressions to definite design features, Environment and Planning B: Planning and Design, 1998, volume 25, pages 825-836

11) Cagri Imamoglu : Complexity, linking and familiarity: architecture and non-architecture turkishstudents'assessments of traditional and modern house facades, Journal of Environmental Psychology (2000) 20, $5-16$

12）君山由良: コンジョイント分析, データ分析研究所, 1999.9

(2012年 6 月 8 日原稿受理, 2012年12月 5 日採用決定 